Volume 5 | Issue 1

2018

\title{
Letter from a Law Teacher
}

Dustin B. Benham

Texas Tech University School of Law

Follow this and additional works at: https://scholarship.law.tamu.edu/lawreview

Part of the Law Commons

\section{Recommended Citation}

Dustin B. Benham, Letter from a Law Teacher, 5 Tex. A\&M L. Rev. Arguendo 37 (2018).

Available at: https://doi.org/10.37419/LR.V5.Arg.3

This Arguendo (Online) is brought to you for free and open access by Texas A\&M Law Scholarship. It has been accepted for inclusion in Texas A\&M Law Review by an authorized editor of Texas A\&M Law Scholarship. For more information, please contact aretteen@law.tamu.edu. 


\title{
LETTER FROM A LAW TEACHER
}

\author{
Dustin B. Benham*
}

The text below is an actual response to a new teacher asking about my approach in the classroom. More than seven years on the job taught me that quality teaching depends on much more than subject-matter expertise and a good PowerPoint.

At the outset, let me apologize for the delay in this message. I was swept up in the end-ofsemester whirlwind. And as I reflected on your questions, I realized an adequate answer would take more than a quick reply.

Your email raises profound questions - questions that go to the core of what it means to be a teacher, lawyer, and human being. It turns out that the balance between commanding respect as an expert, being yourself, meeting student expectations, and getting the nuts-and-bolts work of teaching done is something that I struggle with most days.

Over time, the formula has changed because my students have changed, I have changed, and the material has changed. Even more than this, being a teacher is dependent on "being," which means it is subjective and relative to a degree that giving and receiving any teaching advice is perilous. But despite the difficulty in describing what it is to be a "good" teacher, I would like to share a few pieces of hard-earned wisdom that I wish someone had shared with me at the beginning of this journey.

Most of this advice was born in my failures and mistakes, and I give all of it with humility and acknowledgment that I still have much to learn. Teaching is a craft mastered over a lifetime, not a decade.

At the outset, you should be commended for caring about teaching. Many professors do. Many don't.

"Caring" about teaching really reflects respect for a relationship of trust between student and teacher. This relationship is thousands of years old and embraces the simple notion that human beings can transmit knowledge to, and indeed, better one another. Some professors don't enjoy teaching. Some simply don't care. Some professors prioritize other things above teaching, even if they do care. Research, consulting, and administrative ambitions all compete for a professor's attention. Believe it or not, some academics are skeptical of any teacher's ability to meaningfully affect their pupils' understanding. To these skeptics, students are actually autodidacts who suffer from an illusion of being "taught." The reasoning: it nary matters who is at the front of the room; what matters is the aptitude and diligence of the students.

* Professor of Law, Texas Tech University School of Law. I have removed identifying information about the recipient. The text has also been lightly edited for clarity. Thanks to the many fantastic teachers who have influenced my understanding of teaching along the way. None of them likely would agree with all of the advice I give, but all will recognize traces of their wisdom. In particular, thanks to Rory Ryan, Mark Osler, Walt Huffman, Amy Hardberger, Steve Friedland, Jim Wren, Nancy Soonpaa, and Brian Shannon. Thanks also to Michele Thaetig and John Delony. Special thanks to Chris Ritter, my brother in life and in the Bar, for all the time and care he has invested in me for the last three-plus decades - I hope to pay it forward.

DOI: https://doi.org/10.37419/LR.V5.Arg.3 
All of these approaches ignore something fundamental - the transformative power of the teacher in students' lives. This is a power that extends not just to the subject matter being taught but to students' broader experiences. Indeed, many students (including me) can cite to pivotal teachers who masterfully conveyed material and in the process changed the trajectory of their lives. This power is sacred, and anyone put in a position to teach at any level should consider it carefully.

Teaching matters. So how do you do it?

\section{Be Yourself}

The one rule to hold above all others is to be yourself. Cliché but true. Students, like jurors, smell even a whiff of inauthenticity like bloodhounds. They may not be able to put their finger on precisely what they've detected, but I think students note inauthenticity as a form of un-relatability. Or worse, dishonesty.

And inauthenticity has costs beyond student perceptions. After an episode of inauthenticity as a teacher, you may (consciously or subconsciously) take mental note that you are being phony. This has a ripple effect, generating background mental chatter that may take you out of the moment or at least produce low-level anxiety that is counter-productive to engaged teaching. Being inauthentic takes mental energy, even if subconsciously, that could be better used on the task at hand.

As simple as the advice "be yourself" sounds, it is actually incredibly challenging to practice in a classroom. That's because most of us-yes, even professors-have little clue who we are. In a world busy with writing deadlines, committee meetings, family obligations, and practice obligations, it turns out that earnest self-reflection and examination is an endangered art.

And many of us have made a successful career out of meeting other people's expectations, subordinating our sense of self to the whims of our supervising partners, tenured faculty colleagues, deans, and students. Somewhere along the way, the question "Who am I?" became "Who do you want me to be?" This approach to career and life is antithetical to authenticity-how can you "be yourself" when "yourself" is simply what others wish you to be?

So, any attempt to teach should begin with an exploration of who you really are. This may require going back years, or even decades, to find those roots (perhaps dormant but still there) of your personality and self that preceded your professional life. It may involve sitting quietly with yourself and taking note of what you see. Whatever your approach, you can't be yourself until you really know yourself.

You should always remember that people (including your students and you) are dynamic, not static, and that who you are literally changes with every class. Trying to imitate the professor you were at the beginning of your career, last year, or even last class is another inauthenticity trap. In practice, this means that the effort to know yourself is a lifetime project.

But even then, many questions about being yourself remain, including perhaps the secondmost-challenging - what if "yourself" is something undesirable to students? What if you are a jerk? What then? 


\section{Don't Be a Jerk}

People don't like jerks, and students carry a particular disdain for the jerk teacher. My best guess is that this stems from students perceiving a breach of the trust relationship mentioned above or students resenting captivity. The effect of jerk behavior in a classroom can be catastrophic (all teachers with a little experience (including me) have fallen prey to jerk instincts in weaker moments and most will testify that it undermined the day, the week, or even the semester). Being a jerk to one student derails the day for the class and likely loses the student for the semester.

All of this begs the question, who is the jerk teacher? There are many forms of the classroom jerk with several being common. One variant berates, chastises, or criticizes students in public. This might be done with venom, humor, or a combination of both. While there are few professors still operating in outright Professor Kingsfield mode, many still publicly criticize or belittle students from time to time.

"Wait!" you say, "isn't criticism necessary to education and particularly a lawyer's professional development?" Absolutely. But in my experience, personal criticism should be carried out in private. This rule admits a few exceptions. This doesn't mean that a professor cannot disagree with a student in front of the class, but once that disagreement becomes personal (real examples from my time as a student or teacher: "Why didn't you do the reading?" "You obviously didn't take enough time to understand this." or (Gasp!) "You don't belong in law school. You'll never be a litigator."), it should be carried out in your office, on the telephone, or in an email.

By doing so, you deliver the full impact of the criticism without the accompanying resentment. Limit public comments to praise ("Your analysis is really coming along." "I'm proud of everyone's preparation today." "Keep it up and you'll make a lot of money someday-please remember me and your law school.").

Another variant of the jerk teacher makes everything in the classroom all about himself or herself. Every hypothetical is an angle on a war story from this person's illustrious practice or, even worse, reflected and explained in the person's research. Law teaching seems to draw a disproportionate number of this type of jerk. Perhaps this is because legal academia turns so much on individual reputation and self-promotion. It shouldn't be surprising that some can't turn it off when they stand at the podium. But whatever the cause, students don't like the self-aggrandizing jerk either.

There are other jerk-types too (see, e.g., the "passive aggressive," the "never good enough," the "sadist," the "good luck getting anything approaching an answer from me"). Each of the other law-teacher jerks is a curiosity but doesn't merit more words here - suffice it to say, students don't like any of them.

"But wait!" you might say, "What does it matter if students like you? Your job isn't to be their friend. It's to teach them the law." Fair enough. But it seems students don't learn optimally from people they don't like. The stronger the dislike, the greater the learning impediment. Instead of thinking about your torts hypothetical, students facing the jerk find themselves thinking things like: "When will this end?", "Does this guy really take himself so seriously?", "Please, God don't let him call on me again!", or "Where do a*\#holes like this even come from?"

One of the primary pretexts for public shaming or recrimination in a classroom is that it incentivizes student preparation and participation. But, it costs something too. The anxiety and disdain you create becomes its own distraction, cutting against your students' willingness to listen 
to you. My goal for my students is that they are engaged with the material while they are in my classroom. So, I try to minimize distractions, including my own jerk-dom.

And there can be an even greater cost to your students disliking you-they can come to associate the negative feeling about you with the material you are teaching. If you ask people what their favorite subject from law school (or college) is and then ask if they liked the teacher who taught that subject, they'll almost always answer yes.

I suspect the inverse is true too. Students who hate a particular subject may actually hate the professor who taught them that subject or at least find that professor ineffective. Can I prove cause and effect here? No. But I do note the correlation and would go further to mention that students hating particular legal subjects can have long-term costs.

That's because what we teach is important. I teach evidence, and for all the future litigators in the course, I consider the class among the school's most important. If students leave with a bad taste in their mouths for the subject, that can have consequences for their clients. In short, students liking you is important because learning is important, and the two go hand-in-hand.

This doesn't mean that you should mollify, coddle, soft-peddle, or do anything in those realms. Our students are entering (or are at least interested in entering) a demanding profession, and we serve them well when we are honest with them about that. But in my limited experience, students like me most (and find me most effective) when I am simultaneously demanding and not a jerk.

But what if you are a jerk? Is it game over? Well, possibly. But there is at least some hope. The short answer: you must change and not be a jerk. The longer answer acknowledges that it is very difficult for people to change, but change is possible with self-examination.

If you are a jerk, there's a big chance you've never asked yourself why you are a jerk (there's actually a substantial chance that you do not know you are a jerk). But if you are worried that you are a jerk, that means you probably are a jerk, and it is at least worth considering why. Without delving irresponsibly into rabbit trails about temperament, character, psychology, etc., I'll offer the lay observation that many jerks seem to be fueled, at their core, by insecurity.

Insecurity about rejection, acceptance, love, and companionship can drive people to seek control over interpersonal interactions by belittling others. It can drive people to gloat endlessly about accomplishments in search of acceptance from others. It can make people react viciously when they are challenged and feel threatened. All of this likely stems from a deeper, universally human root-fear of loneliness. It turns out that we are all one step away from being jerks when we don't keep a careful eye on that fear and allow it to control us.

So how do you avoid being a jerk? Realize that when you are at the podium, you are where you are supposed to be. Realize that the natural order is for you to teach and for students to learn and that no one - particularly no student — can derail that by challenging your knowledge or your authority. By being there, you are already a teacher and worthy of respect. And likewise, by being in front of you, your students are also worthy of your respect, whatever their aptitude or level of preparation. Anything that threatens to disrupt this order can be effectively and efficiently handled in private. And also, always remember-it isn't about you.

But the great thing is that I know you are not a jerk, leaving much of the above purely rhetorical. Still, it is worth keeping in mind because if you are like me, you will occasionally find yourself facing down your inner jerk. 


\section{Be Prepared}

This brings me to my next point, and one that will help temper some of the issues mentioned above: be prepared. It's that simple. The key to quality teaching is quality preparation. And a helpful side-effect of thorough preparation is increased confidence at the lectern. Knowing you are the most prepared person in the room, each and every day you teach, is essential to both substantive presentation and reducing jerk-triggering anxiety.

How do you prepare? It is different for every professor and changes over time. When I first started teaching, I viewed prep as the somewhat painful price I paid to step in front of a class. Over time, I began to enjoy preparing a lecture as much or more than delivering it.

As an important aside, the suggestion that you prepare to "lecture" is somewhat dangerous because quality teaching seldom involves straight lecture. You aren't preparing a script or writing a sermon. Nor will you perform a play to a willing audience or preach to a devout congregation.

Instead you will attempt to dynamically engage your students in material that is at best challenging and at worst dense and boring. Occasionally, you will get lucky and succeed at this task. The tactics that might increase your chances depend on the subject matter of the particular class and merit another letter, but the more first-person participatory opportunities you provide the better.

The Socratic method is great for the student responding to the questions and those savvy enough to put themselves in "the shoes" of the person responding. But for many students, the moment a classmate is called on, it is time to count blessings and return to the internet. As my teaching has evolved, I focus much more on preparing in-class exercises, small-group activities, and technology-based solutions to allow the entire class to participate. If you'd like more detail, I'm standing by.

But back to how to prepare for a class: allow plenty of time. And I mean plenty. When I began teaching, I would prepare about four hours for every class hour. Of course, I was young and learning plenty of law myself along the way, so it took time.

As mentioned above, I learned quickly that speeches were tough to memorize and ineffective. Likewise, being married to notes at the podium leaves you stilted and unable to respond to on-thefly developments in class. So return to an old approach to your new role in the classroom: prepare like a student (a really good student).

What does it mean to prepare to teach like you are a student? It means that you approach every class with some plan but no real idea about how things will unfold. It means that you will actually have to prepare more thoroughly than the memorized or note-based approach because you don't know precisely what is going to happen or what might be asked of you. To prepare like a student, you must immerse yourself in the material so that you can catch that fly-ball question and toss an easy underhand for the double play that teaches students something you never dreamed you'd teach that day.

You must know the cases - the facts, the holdings, the precedents they rely upon, the policy they seek to achieve. You must think through variations on the fact patterns in those cases and do a little research to know how things would have turned out if $\mathrm{X}$ were $\mathrm{Y}$. You must know the rules and all the advisory committee comments, and the previous rule versions, and possibly the model rules. You must know the statutes and important legislative history. You must know your textbook 
and its practice problems and notes. You must know the cases that underlie those problems. In short, you must know everything.

But the funny thing is, you won't know everything. Try as you might, you won't be able to check everything off your list, and you'll walk to the podium with a nagging regret about something you left undone. If you can, leave that regret at the door. Leave it at the door with the understanding that if you do $33 \%$ of the above, you will be the most prepared person in that room. And that should be your goal. When you are the most prepared, you are the teacher.

Over time, my preparation time has decreased substantially. I now have to cap my prep time to avoid cutting into other obligations. But if left to my own devices, I could easily spend a halfday on every one-hour class, writing and tweaking hypos, creating exercises, reading more cases and commentary. A few times a semester, I'm guilty of doing just that.

One funny irony of deep preparation, particularly once you become more experienced, is that it can actually cut against quality teaching. Preparing like a student should mean that you come to the material fresh every semester. You examine its structure and break it down into components that your students can digest. You recognize the basic function of each component and its connection to other features of the law. And you tie it all together with its underlying purposes. You do all of this in a simple and straightforward manner.

Deep preparation can be the enemy of this approach. The problem is that the law is seldom simple or straightforward, even where it should be. Complex or bad facts make complex or bad cases. Outlier cases create nuance. And when you know a ton of this nuance, you are tempted to convey it to your students. But the problem is that they don't yet have the scaffolding to hang the nuance upon. And so, the nuance confuses their understanding of the basic framework while they are still building it. As Professor Frank Hanft observed in the Yale Law Journal almost 80 years ago:

The ability to understand complicated cases and to present them as simply as their nature permits, but no more simply, and the power to speak vividly as well as accurately - these elements of adequate law teaching are probably worth more than any method, however good, or any point of view, however sound. ${ }^{1}$

In plain terms - keep it simple within the bounds of accuracy. At least at first. After your students have proven to you that they understand the frame, you may choose to explain a little nuance. Or not. It depends on how important it is. To do this, you must be able to distinguish between what is basic or essential to your students' understanding and what is in a realm beyond that.

Over preparation and subject-matter expertise can make distinguishing between basic and advanced knowledge more challenging. So, prepare, but relish being a beginner. You'll do some of your best teaching this year. Don't forget how you did it.

On a final note about preparation, don't ever forget to prepare to explain why the material is relevant and important. You are not just a teacher; you are an advocate. You are an advocate for your material. Each day, students have a limited attention span. As rational consumers of information, they spend that attention on what they deem important or entertaining or both. For

${ }^{1}$ Frank W. Hanft, Legal Education Yields to the Times, 47 YALE L.J. 214, 214 (1937). 
example, explaining why a certain element is important to understanding a certain tort and why that tort is important to their understanding of torts generally and then reminding them of how central torts is to the law or even the order of the world is essential.

When I teach something as pedestrian as attorney fees in professional responsibility, I often begin each class by saying, "Here's another lesson in how to get paid and keep the money." Needless to say, I have their full attention for the day. You are competing in a marketplace for student attention - be the class they care about and remind them why daily.

\section{Listen (and Look)}

You will be well prepared. And because you are prepared, much of the rest of "teaching" will unfold in the classroom as it should.

But I would be remiss not to mention that you should always listen to your students when you teach (seemingly obvious but difficult in practice). Listening allows you to know where the class actually is and where it should go.

Assuming you come to class with a plan, listening to your students' responses and questions allows you to assess whether and to what extent that plan is working and whether you ought to ditch it for another path. Sometimes you will pitch a softball question to your class, only to realize that the material you assumed was simple is actually quite difficult. Other times, you will ask a question and the response will be rapid and delivered with a tone of exasperation at your snail's pace. Sometimes a student question will make you explore a fundamental aspect of the law that you assumed everyone already knew. Other times a question might put you down a rabbit trail that confuses everyone. ${ }^{2}$ Put simply, if you aren't listening to your students, in both their words and tone, you are lost as a teacher.

So why would any competent teacher not listen? There are lots of reasons. Listening is hard. It is even harder when you have 50 pairs of eyes staring you down, and all the extraneous body language in the room is distracting you from the student speaking.

Also, that plan you made (see Be Prepared, supra) took a lot of time. And you'll invariably have the instinct to protect the time investment by over-managing the discussion (e.g. not listening or disregarding what you hear). The clock at the back of the room will move at double the speed of regular clocks, always leaving you with too little time to cover what you wanted. Student questions will start to look like hurdles to overcome on your way to a self-imposed finish line. All of this is natural, and I still wrestle with these urges on a weekly (if not daily) basis.

The cost of not listening, however, is profound. As mentioned above, it leaves you lost in your own classroom. Worse yet, not listening or not caring about what you do hear squelches student participation. Taking a dismissive tone toward a question tells all students that you have things to get done that are more important than questions. A non-responsive answer to a question makes students doubt whether you are listening and whether their questions are worth the effort. Asking a question in front of 50 people is actually quite scary to most law students. Commend your question-asking students' bravery with a thoughtful, enthusiastic response.

You should also look at your students. Not just in their general direction. Look at them. Make eye contact, read body language, smile. Students convey a ton of non-verbal information, some

\footnotetext{
${ }^{2}$ Cf. Benham, Questions to Answer After Class (forthcoming, maybe).
} 
accurate, some not-so-accurate. You'll notice the "nodders" first. They'll smile and nod through most of the class, and this is very reassuring encouragement.

More helpful (though less encouraging) than the nodders are the "doubters," students who visibly express frustration with your explanation or answer to a hypothetical. They may grimace, snarl, roll eyes, shrug, or engage in a variety of other conduct that basically all boils down to "That doesn't make sense." After you get a sense of these students' abilities (are they a top, middle, or struggling student?) you can use them as a barometer for the rest of the class's understanding.

And you'll need barometers, because most students in your class will stare at you, or stare at something else, blankly. And I mean deadpan blank. This phenomenon can be unsettling at first because it is hard to believe you are doing a good job as a teacher when a significant portion of your class is staring at you (or the wall, or a laptop) catatonically. Shortly after I began teaching, a kind and wise colleague asked me how it was going. I told him, "Who knows? They look like they are dying out there."

He shared some great wisdom and told me to go to a movie that weekend, and when at the theater, to look behind me at the audience watching the movie. I followed his advice, and I saw the same blank stares as looked out at me in class. The movie was very good, yet everyone looked like zombies watching it. The same is true in a classroom-most students don't see it as a twoway interaction when they aren't being called on. You are the show, and they are watching the show. Don't be unnerved by those who choose not to visibly react. Unless $100 \%$ of the class has blank stares - that's a problem.

All of this boils down to simple but difficult advice: be present. Be present in your classroom, not glued to an outline, or staring at the clock, or sequestered in your own head by the overwhelming experience of being at the front of the room. See and hear your students for who they are-people of various abilities and understanding who are counting on you to steer the ship.

\section{Don't Judge}

There will come a day when your students disappoint you. That day will come very soon. How you handle that moment, and other moments like it, will affect the quality of your teaching and, believe it or not, the quality of your broader life.

The disappointment could be small (a student unprepared for a question) or large (a student cheats on a test or personally attacks you for his or her own failing). These disappointments happen too frequently, so you might want to put some thought into how you'll handle the situation.

When something goes "wrong" in life, humans have a tendency to tell a simple, post-hoc story about it that assigns responsibility to a bad actor or actors. Lawyers have long capitalized on this part of human nature by boiling down factual occurrences into narratives and legal theories that sort out the responsible from the not responsible, guilty from innocent, those worthy of condemnation and those who are not.

I often tell my evidence and trial advocacy students that if they can't explain their theory of the case to me in 30 seconds or less then they haven't thought about it enough. The truth is that I am encouraging them to oversimplify a complex story (e.g. murder) to effectively communicate with a jury, at least in part by taking advantage of the human tendency to see things after the fact as a simple story that attributes fault in black and white. This makes for fantastic trial advocacy, 
but should you let the simple fault narrative infect your classroom or your broader life, you could be less effective or worse yet, unhappy.

An example: A student shows up to class. You call on him. He tells you he hasn't read. Your teacher's mind may have the tendency to jump to a familiar narrative (one that was given to you by your own professors and (later) bosses). “This student just doesn't care. He isn't diligent. He's not taking care of his business. My class just isn't his priority. If he keeps this up, he'll hurt a client someday."

This is a grim view of your student and one that may have little basis in fact. Your student may be sick, grieving the loss of a loved one, he may be in a fight with a girlfriend or spouse, he may have a sick kid, he may have just forgotten, he could be terrified to speak in public, you may have forgotten to assign those pages, or he could in fact be lazy. The truth is, you don't know.

But by holding the little mini-trial in your own mind, you've condemned him. Stay away from this poison. Even if you do the right thing by not voicing your thoughts (see Don't Be a Jerk, supra), thinking this way has consequences. Your body language will speak volumes. Worse yet, if condemnatory thoughts become habitual when you interact with students, your classroom will probably become more adversarial. And you'll enjoy being there less. Viewing your students in these terms, even if just the fraction of students you deem problematic, can sap your motivation.

It will take work to keep an open mind when your students disappoint you, and it is even harder when they disappoint you in bigger ways than taking a pass in response to a question.

What does this work look like? It starts with communication. If a student disappoints you in the classroom, send them an email or pull them aside in a discreet way. Let them know you are disappointed in what you saw and, more importantly, worried about them. Ask them if you can help. Ask them what is going on. In short, view the disappointment as an opportunity to get a better view into at least one mind in your classroom.

I've never been disappointed at what I've learned in such interactions. They have given me the opportunity to build stronger relationships with students who need help and hopefully I've helped a few of them.

And when you are able to stay away from the mental mini-trial of your students' conduct and ability, your teaching will benefit. You'll show up each day to work to teach human beings who are trying their best but who are imperfect. And in that way, your students are a lot like me and probably like you, too. With this more realistic, more nuanced view, you'll be happier in the classroom and that pays enormous dividends.

\section{Do Care}

Treat each time you are in front of a class as a sacred opportunity. Because it is. Care about your students as human beings. Care about the craft of teaching and see each moment as a step in a multi-year journey, one in which you may never be perfect, or even proficient, but one in which you'll give your best. Care about the law, about our nation, and about the world. When you work with hundreds, or thousands, of students over a career, you are creating many ripples that have the capacity for much positive change.

Care about yourself, your own heart, and your own mind. The secret to teaching is that it is actually just you up there. The "you" that has a brilliant thought along with the "you" that has a dumb idea or a terrible day. 
It turns out that much of the advice I could give about teaching, I could give about life. Being authentic, kind, present, and free from judgment probably enhance the chances you have a happy, satisfied life. When you do, you'll be able to move seamlessly between the classroom and the rest of the world without thinking too much about what it means to be a good teacher because that will just mean being you.

Thank you for giving me the opportunity to share some thoughts with you. It's been an amazing voyage, and I'm hopeful that teaching will be a wonderful part of your life too. Please let me know if I can ever assist in the future. 